\title{
Yield reduction of oat cultivars in relation to disease development caused by barley yellow dwarf virus
}

\author{
P. PELTONEN-SAINIO ${ }^{1}$ and R. KARJALAINEN ${ }^{2}$ \\ ${ }^{1}$ Department of Crop Husbandry, University of Helsinki \\ 00710 Helsinki, Finland \\ ${ }^{2}$ Department of Plant Pathology, University of Helsinki \\ 00710 Helsinki, Finland
}

\begin{abstract}
The effects of barley yellow dwarf virus on the development, grain yield and yield components of oat cultivar Veli and breeding lines Hankkija 78152 and 78033 were studied in two years. Cultivar differences to BYDV infection were best observed at a low infection level. Single tiller analysis indicated close correlation between symptom severity and reduction in main yield components. Early infection caused greatest yield losses in all cultivars. BYDV strongly reduced both plant height and harvest index. Mild infection reduced the grain yield by $2-8 \%$, but severe infection by $36-41 \%$. The number of grains and panicle weight were strongly reduced, but the 1000-grain weight was only slightly affected after severe BYDVinfection. Implications of these results for disease control are discussed.
\end{abstract}

Index words: barley yellow dwarf virus, yield loss, epidemiology

\section{Introduction}

Barley yellow dwarf virus (BYDV), the type member of the plant luteovirus group, is transmitted in a persistent circulative manner by aphids (Oswald and Houston 1951). Five distinct isolates of BYDV (MAV, RPV, RMV, SGV, PAV) have been described in northern America (Rochow 1977, 1979). BYDV is the cause of a serious virus disease on main cereal species all over the world (Plumb 1977), and crop losses of up to $70 \%$ have been reported (Gill 1980).
Rational disease control strategies require information of yield losses caused by the disease. BYDV occurs in Finnish oat fields nearly every year, and if the weather favours the early spread of aphids into the field, significant yield losses are likely to occur. Oat fields in Finland are often small and situated at some distance from the main farm, and therefore the monitoring of aphids may be difficult resulting in great yield losses.

This study was designed to provide infor- 
mation of how BYDV affects oat yield characteristics, at what time of plant growth infection affects yield most seriously, and how cultivars differing in their susceptibility to BYDV suffer from the disease. The results reported here are from two years, 1986, when infection was moderate, and 1988, when infection pressure was very high.

\section{Materials and methods}

The data reported in this study are based on two years' field experiments carried out at Viikki Experimental Farm of the University of Helsinki. Three spring oat genotypes were selected for the trials, cultivar Veli, susceptible to BYDV, and lines Hankkija 78033 and 78152 (from now on referred to as $\mathrm{Hja} 78033$ and 78152), moderately resistant or less susceptible to BYDV. Randomized block design was used in both years, and the trials were set up with six replications, half of which were inoculated with aphids. Plot size was $10 \mathrm{~m}^{2}$ and normal herbicide treatments and fertilization levels were used. Inoculated plots were surrounded by guard plots in order to prevent virus-transmitting aphids from spreading into control plots.

In Finland, barley yellow dwarf virus is effectively transmitted by Rhopalosiphum padi. Therefore, samples of $R$. padi were collected from the fields near the trial field, and they were put into a breeding cage, where the aphid population rapidly increased. Inoculation with aphids was done according to RUSSELL (1978) and GiLl (1980) so that small pieces of oat leaves containing aphids were distributed in the central parts of the plots. When the leaf pieces died, the aphids moved to the neighbouring oat plants. The number of aphids per tiller was monitored in infected and control plots, and an exact number of aphids was added to all infected plots.

Control plots were kept free from aphids by spraying them regularly with insecticides. In 1988 (26. 6.), all aphids were controlled by insecticides in order to avoid damage caused by insects to the crop. Also, in 1988 the natural spread of aphids was so effective that artificial infection was not needed. Virus concentration in plants at various stages of development was monitored by ELISA (CLARK and ADAms 1977) using RPV antiserum.

Several parameters were recorded during the growing period. Plant height was measured six times from ten plants per plot. The development of green-leaf area was monitored by estimating the non-green leaf area on three upper leaves once a week from 60 plants per plot. It appears to be more accurate to estimate the non-green leaf area than the greenleaf area.

Two kinds of disease measurements were carried out. The development of BYDV in whole plots was monitored once a week by estimating the number of BYDV-infected plants per plot using the following scale:

\begin{tabular}{lc}
\hline Class & $\begin{array}{c}\text { Number of BYDV-infected } \\
\text { plants per plot }\left(10 \mathrm{~m}^{2}\right)\end{array}$ \\
\hline 1 & $0-3$ \\
2 & $4-6$ \\
3 & $7-14$ \\
4 & $15-25$ \\
5 & $26-44$ \\
6 & $45-74$ \\
7 & $75-111$ \\
8 & $112-186$ \\
9 & over 186 \\
\hline
\end{tabular}

In addition, single-tiller analyses were carried out according to RichARDSON et al. (1975) and KING (1976). Five hundred tillers of the Finnish variety Puhti were labelled and rated for disease severity according to the following scale:

\begin{tabular}{cc}
\hline Class & $\begin{array}{c}\text { Flag leaf BYDV } \\
\text { diseased leaf area } \%\end{array}$ \\
\hline 1 & 0 \\
2 & $1-30$ \\
3 & $31-60$ \\
4 & $61-90$ \\
5 & $91-100$ \\
\hline
\end{tabular}

In this case infection time was observed and the tillers labelled. The labelled tillers were col- 
lected before harvest and subjected to yield component analysis.

In the single tiller test the mean value of 100 tillers was used in each disease class for comparing the relationship between disease severity and yield components. In a large scale test, grain yields and thousand grain weights were determined after harvest. The data were subjected to several statistical analyses. Correlation and regression were computed between disease severity and yield components. Yield analysis was done by variance analysis.

\section{Results}

\section{Disease development}

In all experiments, Veli was most susceptible to infection by barley yellow dwarf virus, and Hankkija's breeding lines were less susceptible. Cultivar differences were clear indicating that our inoculation technique works under field conditions. Veli was about twice as infected as $\mathrm{Hja} 78152$.

In 1986, infection started at a later stage of oat development, but the number of aphids in the field increased rapidly, and the virus was quickly transmitted throughout the field (Fig. 1). Also, in 1986 the growing season was warm, and rainfall was below normal most of the season. High temperature favoured the rapid spread of the aphids in the latter part of crop growth.

In 1988, cultivar differences were less clear, although Veli was still consistently more susceptible than the other cultivars. In 1988 the growing season was exceptional in many aspects. Throughout the season, rainfall was below normal and the temperature was exceptionally high. As the weather was favourable for aphids, BYDV infection progressed rapidly in early growing season (Fig. 2), and in 1988 the oat plots were already completely infected by the time infection had only started in 1986 . Aphids spread naturally very early into the plots in 1988 compared with 1986. Despite several chemical treatments to control aphids

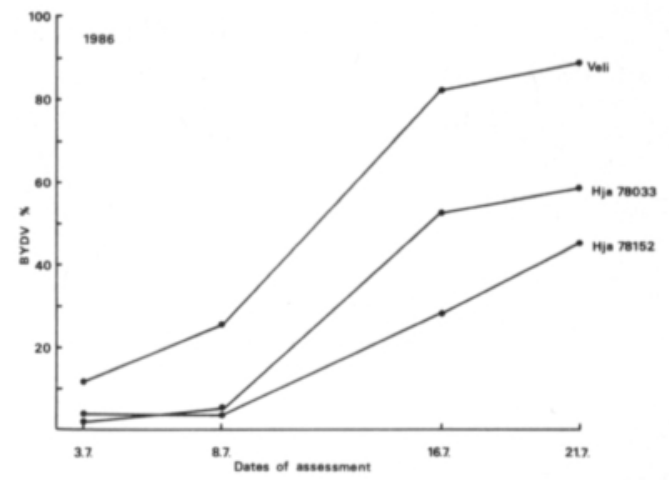

Fig. 1. Disease development of barley yellow dwarf virus (BYDV) on three oat cultivars in 1986.

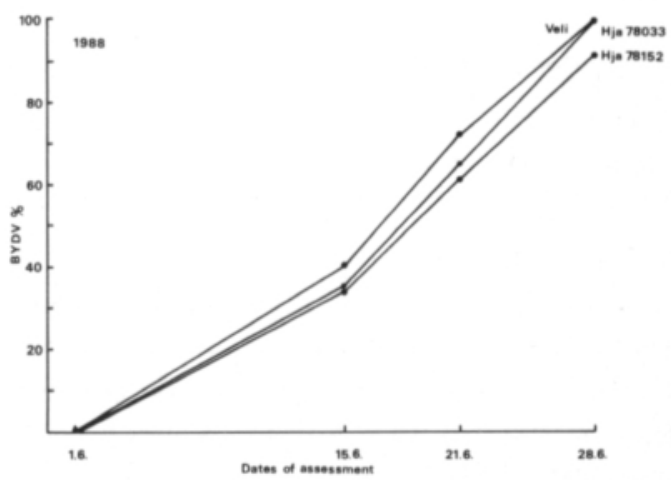

Fig. 2. Disease development of BYDV on three oat cul. tivars in 1988.

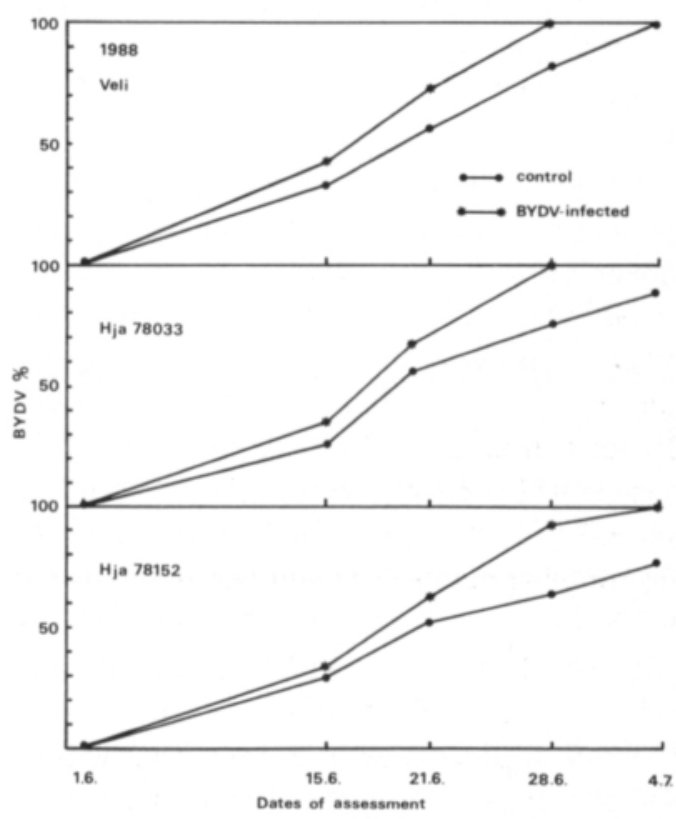

Fig. 3. Disease development of BYDV on three oat cultivars in control and BYDV-inoculated plots in 1988. 


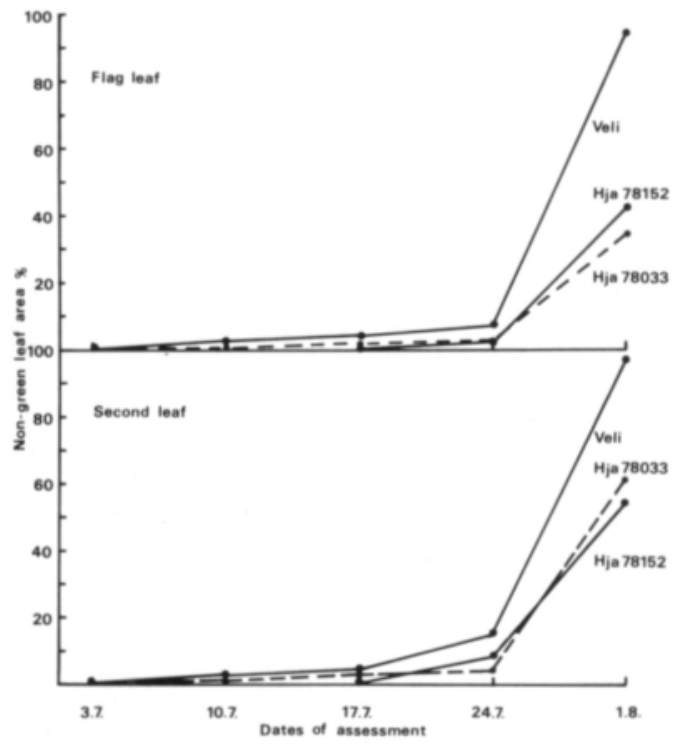

Fig. 4. Development of non-green leaf area on three cultivars under disease stress caused by BYDV in 1986.

in control plots, we were unable to totally prevent them, and there was some BYDV in control plots in both years (Fig. 3). Virus concentration as determined by ELISA was highest when $50 \%$ of the leaf area was infected.

Reduction in the green-leaf area related to disease development was estimated by evaluating the non-green leaf area once a week (Fig. 4). The green-leaf area on the two uppermost leaves was first destroyed in Veli and later in both lines. This suggests that the length of green-leaf area duration might be one component of resistance in oats to barley yellow dwarf virus.

\section{Effects of BYDV infection on plant growth and yield}

In order to assess how symptom severity is correlated with main yield components of oats, extensive single-tiller analyses were made from samples collected in a naturally infected oat field of cultivar Puhti. The results indicate (Table 1) that all yield components were reduced as virus symptoms increased. The number of grains was less affected than grain weight or panicle weight, which might be due to the compensation effect (Fig. 5).
Table 1. Relationship between disease severity of barley yellow dwarf virus and oat yield components.

\begin{tabular}{lccc}
\hline $\begin{array}{l}\text { Disease severity } \\
\text { on flag leaf } \\
\%\end{array}$ & $\begin{array}{c}\text { 1000-grain } \\
\text { weight } \\
\mathrm{g}\end{array}$ & $\begin{array}{c}\text { Number } \\
\text { of grains }\end{array}$ & $\begin{array}{c}\text { Panicle } \\
\text { weight } \\
\mathrm{g}\end{array}$ \\
\hline 0 & 32.5 & 44 & 1.443 \\
15.5 & 33.1 & 44 & 1.459 \\
45.5 & 27.7 & 38 & 1.067 \\
75.5 & 29.5 & 40 & 1.213 \\
100 & 27.3 & 40 & 1.092 \\
Significance & $* * *$ & $* *$ & $* * *$ \\
H.S.D.5 & 1.6 & 5 & 0.166 \\
\hline
\end{tabular}

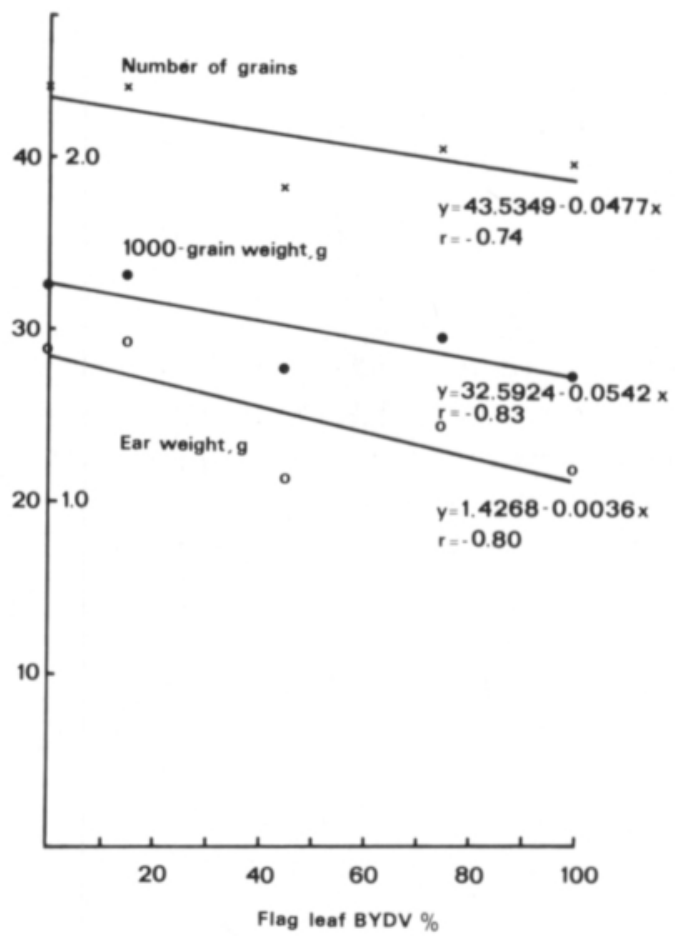

Fig. 5. Relationship between yield components and BYDV disease severity of oat cultivar Puhti.

Further, samples from the three cultivars were taken at different stages of infection in order to clarify how infection time affects yield components. The results consistently showed (Table 2) that early infection caused greatest yield losses in all cultivars.

Grain weight was particularly affected by early BYDV infection (Fig. 6). This experiment confirms field observations about early infestation of aphids leading to significant 
Table 2. Effect of infection time by barley yellow dwarf virus on oat yield components. $\mathrm{A}=\mathrm{Veli}, \mathrm{B}=\mathrm{Hja} \mathbf{7 8 0 3 3}$, $\mathrm{C}=\mathrm{Hja} 78152$.

\begin{tabular}{|c|c|c|c|c|c|c|c|c|c|}
\hline \multirow[t]{2}{*}{$\begin{array}{l}\text { Infection } \\
\text { time }\end{array}$} & \multicolumn{3}{|c|}{$\begin{array}{c}\text { 1000-grain weight } \\
\mathrm{g}\end{array}$} & \multicolumn{3}{|c|}{$\begin{array}{c}\text { Panicle weight } \\
\mathrm{g}\end{array}$} & \multicolumn{3}{|c|}{ Number of grains } \\
\hline & A & B & $\mathrm{C}$ & A & B & $\mathrm{C}$ & A & B & $\mathrm{C}$ \\
\hline Early & 21.3 & 21.4 & 18.7 & 0.817 & 0.761 & 0.715 & 38 & 35 & 39 \\
\hline Late & 31.5 & 32.4 & 31.5 & 0.908 & 1.616 & 1.391 & 28 & 50 & 43 \\
\hline Control & 34.7 & 34.7 & 33.5 & 1.438 & 2.087 & 1.612 & 42 & 60 & 48 \\
\hline Significance & $* * *$ & $* * *$ & $* * *$ & $* * *$ & $* * *$ & $* * *$ & $* * *$ & $* * *$ & $* *$ \\
\hline H.S.D. $5 \%$ & 1.7 & 2.1 & 1.6 & 0.207 & 0.259 & 0.166 & 6 & 8 & 5 \\
\hline
\end{tabular}

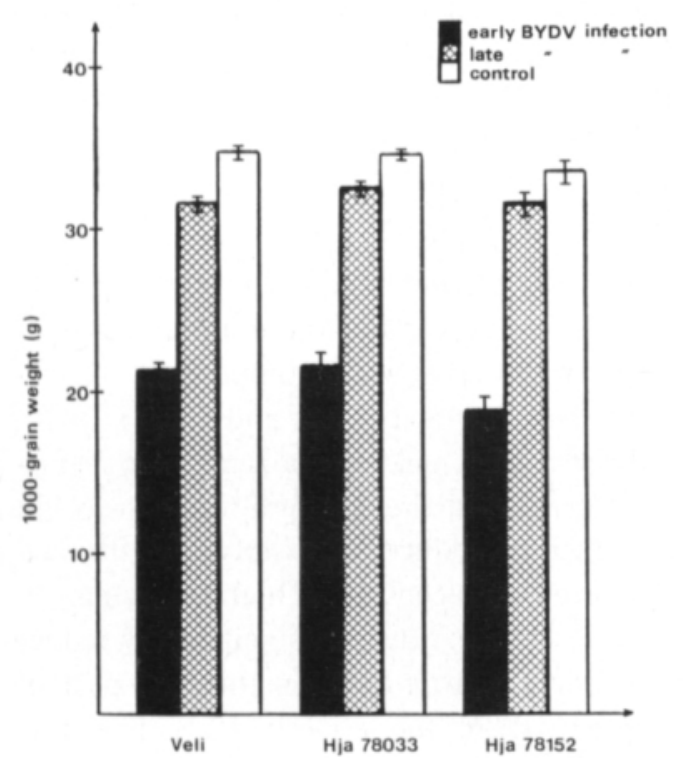

Fig. 6. Effects of BYDV infection time on the 1000-grain weights of oat cultivars Veli, $\mathrm{Hja} 78033$, and $\mathrm{Hja} 78152$. crop losses. As expected, BYDV infection reduced plant height even under moderate disease pressure (Table 3), and it also appeared to reduce harvest index by $5-10 \%$ (data not shown). Table 4 summarizes yield component data from the 1988 experiment. It is evident that panicle weight and grain number are strongly affected by BYDV infection in all cultivars, but only the grain weight of $\mathrm{Hja} 78152$ was statistically significantly reduced. This re-

Table 3. Effect of BYDV-infection on plant height (cm).

\begin{tabular}{lrcc}
\hline & Veli & Hja 78033 & Hja 78152 \\
\hline Control & 68.0 & 63.2 & 69.5 \\
BYDV-infected & 61.7 & 57.0 & 62.5 \\
Difference & 6.3 & 6.2 & 7.0 \\
Significance & $* * *$ & $* * *$ & $* * *$ \\
H.S.D.5 $*$ & 2.1 & 2.1 & 2.0 \\
\hline
\end{tabular}

Table 4. Effects of BYDV-infection on yield components in 1988.

\begin{tabular}{|c|c|c|c|c|c|c|}
\hline \multirow[t]{2}{*}{ Yield component } & \multicolumn{6}{|c|}{ Cultivar } \\
\hline & \multicolumn{2}{|c|}{ Veli } & \multicolumn{2}{|c|}{ Hja 78033} & \multicolumn{2}{|c|}{$\mathrm{Hja} 78152$} \\
\hline \multicolumn{7}{|l|}{ Number of grains } \\
\hline Control & 34.7 & 100 & 33.1 & 100 & 39.9 & 100 \\
\hline BYDV-infected & 27.0 & 78 & 23.6 & 71 & 27.4 & 69 \\
\hline Significance & $* * *$ & & $* * *$ & & $* * *$ & \\
\hline H.S.D. $\%$ & 3.1 & & 3.0 & & 2.7 & \\
\hline \multicolumn{7}{|l|}{ Panicle weight $(\mathrm{g})$} \\
\hline Control & 0.86 & 100 & 0.98 & 100 & 1.06 & 100 \\
\hline BYDV-infected & 0.68 & 79 & 0.68 & 69 & 0.69 & 65 \\
\hline Significance & $* * *$ & & $* * *$ & & $* * *$ & \\
\hline H.S.D. $5 \%$ & 0.09 & & 0.10 & & 0.09 & \\
\hline \multicolumn{7}{|c|}{1000 -grain weight $(\mathrm{g})$} \\
\hline Control & 24.2 & 100 & 28.8 & 100 & 25.5 & 100 \\
\hline BYDV-infected & 24.7 & 100 & 27.6 & 96 & 24.1 & 95 \\
\hline Significance & N.S. & & N.S. & & $*$ & \\
\hline H.S.D. $\%$ & 0.9 & & 1.2 & & 1.3 & \\
\hline
\end{tabular}

N.S. = non-significant 
Table 5. Effects of BYDV-infection on grain yield of oat cultivars in 1986 and 1988.

Cultivar

Veli $\quad \mathrm{Hja} 78033 \mathrm{Hja} 78251$

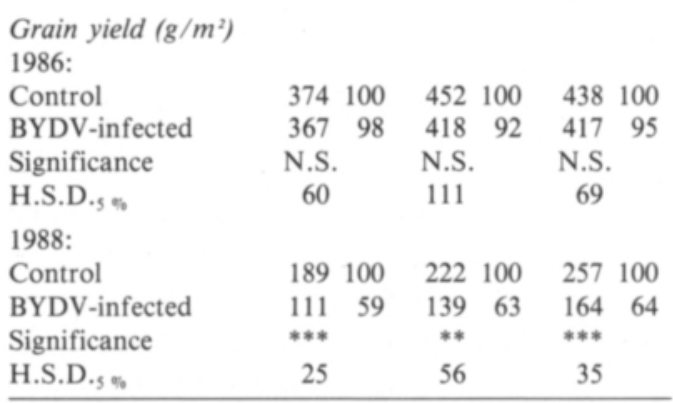

N.S. = non-significant

sult deviated from our 1986 data, where the grain weight of all cultivars was affected, and further data are thus needed to confirm the role of grain weight in yield losses.

Grain yield measurements from infected and control plants indicated (Table 5) that no statistically significant yield losses were noticed in 1986, but in 1988 all cultivars were significantly affected, yield reductions being $36-41 \%$. In general, grain yield measurements are affected by large plot variation, and yield component analyses are needed to clarify the effects of disease on yield characteristics.

\section{Discussion}

The data presented in this study clearly indicate that barley yellow dwarf virus, when it occured early in plant development, reduced all major yield components as well as plant height thus lowering the total grain yield. A crop loss study made in Australia (SмітH and SмIтH 1982) revealed that early inoculation of wheat with BYDV reduced yield from 9 to $79 \%$, while late inoculation lowered it only by 6 to $9 \%$. Recent data by Gildow and FrANK (1988) also emphasize the importance of early infection by BYDV in reducing oat yield thus confirming some previous crop loss studies (ENDO and Brown 1957, YounT et al.
1985). It seems apparent that when BYDV infects oats at an early stage of crop growth, the virus reduces tillering and increases floral abortion, which has negative effects on yield components and the total grain weight. In addition, infection may reduce root development (BURNETT 1984), which could disturb water and nutrient uptake from the soil. BYDV infection also accelerates the senescense of leaves thus reducing overall photosynthesis. This may explain the reduction in 1000-grain weight and panicle weight. In most studies (Boulton and Catherall 1980, Burnett and Gill 1976, PARRY and HABGOOD 1986) grain weight and panicle weight were reduced by BYDV infection.

Here we present results from two years. In 1986 infection occurred late in oat development, when most yield components had already been formed (TENG and GAUNT 1980). However, most yield components were strongly affected, but the total grain yield was not significantly reduced. Possibly the virus did not reach a concentration high enough to induce disease and did not significantly reduce total yield. Particularly in the first part of summer 1986, the cool weather probably slowed down the activity of aphids, which delayed the onset of BYDV infection. However, when the weather warmed up later, the number of aphids rapidly increased and BYDV was transmitted into oat fields (Fig. 1).

In 1988 , it was very warm throughout the summer, and aphids spread rapidly at an early stage of oat development (Fig. 2). All yield components were strongly reduced, and the total grain yield was also significantly reduced. Our results confirm some previous data (Sмітн and Sмітн 1982) which suggest a linear relationship between the percentage of plants infected with BYDV at an early stage of crop growth and grain yield.

Development of barley yellow dwarf disease on three cultivars revealed that Veli was always the most susceptible and $\mathrm{Hja} 78152$ the most resistant one. Our data also suggest that cultivar differences are best observed when in- 
fection is moderate, as in 1986. Further, our inoculation technique appeared to work well, and differences in oat cultivar resistance to BYDV can be screened using such a field method. Many barley cultivars carry specific resistance genes to BYDV (JEDLINSKI 1984), but in oat cultivars the resistance is mainly non-specific (COMEAU 1984). However, several oat cultivars with high level of resistance have been released (e.g. BROWN and JEDLINSKI 1978).

Resistance in oats to BYDV appears to correlate with virus concentration (HAMMOND et al. 1983, SKARIA et al. 1985), and breeders have used virus concentration as a selection criterium to improve the resistance of oat lines to BYDV. In this study, virus concentration was monitored by ELISA and using antiserum against an RPV isolate. This antiserum reacted well with the isolates occurring in the test fields indicating that BYDV was transmitted mainly by Rhopalosiphum padi and perhaps by Sitobion avenae. The highest virus concentration occurred when the visually estimated leaf disease severity was around $50 \%$.

Harvest index has also been correlated with BYDV resistance in the field (COMEAU and BARNETT 1979), and our results showed that BYDV infection clearly reduced it. In addition, we found that green-leaf area duration might also be a valuable trait describing oat cultivar resistance to BYDV. In all cases the most resistant cultivars appeared to have the longest period of green-leaf area duration. As this character is rapid and easy to measure, it might be a practical way to improve the resistance to BYDV. However, it is important first to test whether improved resistance to BYDV can be screened by this method without increasing late maturing genotypes in oat populations.

In summary, these experiments have demonstrated that barley yellow dwarf virus, when it occurs early in the growing season, can cause significant yield reductions. Average annual crop losses in the USA are $3.8 \%$, about $2 \%$ in Australia, and $7 \%$ in Canada (GILL 1980, BuRneTt 1984). However, once in every $5-7$ years, an epidemic spread of BYDV can cause $20-30 \%$ yield reductions. Similar type of crop losses are also likely to occur in Finnish oat fields. For instance, a rather late and moderate infection in our 1986 experiment reduced all yield components indicating that even a late infection has a potential to reduce yield. However, when infection starts early, and the weather favours aphid development, drastic yield losses are evident, as was shown in the 1988 experiment.

Acknowledgements. Financial support from the Academy of Sciences and the Ministry of Agriculture and Forestry is greatfully acknowledged. We are grateful to $\mathrm{Mr}$ Jouko Närhi and Ms Elina Rantala for technical assistance and to Dr Rose (Scotland, U.K.) for the kind gift of the RPV antiserum.

\section{References}

Boulton, R.E. \& Catherall, P.L. 1980. The effect of increasing dosage of barley yellow dwarf virus on some resistant and susceptible barleys. Ann. Appl. Biol. 94: 69-75.

Brown, C.M. \& JedlinsKı, H. 1978. Registration of 13 germplasm lines of oats. Crop Sci. 18: 1098.

Burnett, P.A. 1984. Preface. In Barley yellow dwarf. Proceedings of the workshop. p. 6-13. Сıммүт, Mexico.

— \& Gill, C.C. 1976. The response of cereals to increased dosage with barley yellow dwarf virus. Phytopath. 66: 646-651.

Clark, M.F. \& Adams, A.N. 1977. Characteristics of the microplate methods of enzyme-linked immunosorbent assay for the detection of plant viruses. J. Gen. Virol. 34: $475-483$.

COMEAU, A. 1984. Barley yellow dwarf virus resistance in the genus Avena. Euphytica 33: 49-55.

- \& Barnett, G. 1979. Effect of barley yellow dwarf virus on $\mathrm{N}, \mathrm{P}, \mathrm{K}$ fertilizer efficiency and on the harvest index of oats. Can. J. Plant Sci. 59: 43-54.

Endo, R.M. \& Brown, C.M. 1957. Effect of yellowdwarf on the yield of oats. Agron. J. 49: 503-505.

Gildow, R.E. \& FranK, J.A. 1988. Barley yellow dwarf 
virus in Pennsylvania: effect of the PAV isolate on yield components of Noble spring oats. Plant Dis. 72: 254-256.

Gılı, C.C. 1980. Assessment of losses on spring wheat naturally infected with barley yellow dwarf virus. Plant Dis. 64: 197-203.

Hammond, J., Lister, R.M. \& Foster, J.E. 1983. Purification, identity and some properties of an isolate of barley yellow dwarf virus from Indiana. J. Gen. Virol. 64: $667-676$.

JedLINSKı, H. 1984. The genetics of resistance to barley yellow dwarf virus in oats. In Barley yellow dwarf. A proceedings of the workshop. p. 101-105. СімMYT.

KING, J.E. 1976. Relationship between yield loss and severity of yellow rust recorded on a large number of single stems of winter wheat. Plant Pathol. 25: 172177.

Oswald, J.W. \& Houston, B.R. 1951. A new virus disease of cereals, transmissible by aphids. Plant Dis. Rptr. 35: 471-475.

PARRY, A.L. \& HaBgood, R.M. 1986. Field assessment of the effectiveness of a barley yellow dwarf virus resistance gene following its transference from spring to winter barley. Ann. App. Biol. 108: 395-401.

Plumb, R.T. 1977. Grass as a reservoir of cereal viruses. Ann. Phytopathol. 9: 361-364.

\section{SELOSTUS}

\section{Viljan kääpiökasvuviroosin eteneminen kaurakasvustoissa ja vaikutus kauran sadonmuodostukseen}

\section{Pirjo Peltonen-Sainio}

\section{Kasvinviljelytieteen laitos}

Helsingin yliopisto, $00710 \mathrm{Helsinki}$

\section{Reijo Karjalainen \\ Kasvipatologian laitos \\ Helsingin yliopisto, $00710 \mathrm{Helsinki}$}

Helsingin yliopiston koetilalla tutkittiin vuosina 1986 ja 1988 ohran kääpiökasvuviruksen (barley yellow dwarf virus, BYDV) vaikutusta kauran sadonmuodostukseen. Tutkimuksen tarkoituksena oli selvittää tuomikirvojen (Rhopalosiphum padi) levittämän BYDV:n etenemistă eriasteisesti alttiissa kauroissa ja infektion vaikutusta jyväsatoon ja satokomponentteihin.
Richardson, M.J., Jacks, M. \& Smith, S. 1975. Assessment of loss caused by barley mildew using single tillers. Plant Pathol. 24: 21-26.

Rocнow, W.F. 1977. Dependent virus transmission from mixed infections. Aphids as virus vectors, ed. Harris, K.F. \& Maramorosch, K. p. 253-273. New York.

- 1979. Field variants of barley yellow dwarf virus: detection and fluctuation during twenty years. Phytopathol. 69: 655-660.

Russell, G.E. 1978. Plant breeding for pest and disease resistance. 485 p. London.

Skaria, M., Lister, R.M., Foster, J.E. \& Shaner, G. 1985. Virus content as an index of symptomatic resistance to barley yellow dwarf virus in cereals. Phytopathol. 75: 212-216.

Sмiтh, P.R. \& Sмiтh, R.J. 1982. Crop loss assessment studies on the effects of barley yellow dwarf virus in wheat in Victoria. Aust. J. Agric. Res. 33: 179-185.

TEng, P.S. \& Gaunt, R.E. 1980. Modelling systems of disease and yield loss in cereals. Agric. Systems 6: $131-154$.

Yount, D.J., Martin, J.M., Carroll, T.W. \& Zaske, S.K. 1985. Effects of barley yellow virus on growth and yield of small grains in Montana. Plant Dis. 69: $487-491$.

Ms received October 16, 1989
Koejäseninä olivat ohran kääpiökasvuvirukselle selvăsti altis lajike Veli sekä jalostuslinjat $\mathrm{Hja} 78033$ ja $\mathrm{Hja}$ 78152, jotka Hankkijan kasvinjalostuslaitoksen aiempien havaintojen mukaan ovat Veli-kauraa kestävämpiä BYDV-saastuntaa vastaan.

BYDV:n vaikutusta kauran sadonmuodostukseen tutkittiin seuraamalla kasvustojen pituuskasvua ja merkit- 
semällä kasvustosta eriasteisesti saastuneita kasveja, jotka kerăttiin pois tuleentumisen jălkeen. Näistă punnittiin röyhypaino, 1000 jyvăn paino ja laskettiin röyhyn jyvälukumäără. Koeruutusadot puitiin ja punnittiin. Itse taudin etenemistä tutkittiin laskemalla BYDV-saastuneiden kasvien lukumaaără koeruuduissa kerran viikossa. Lisăksi kunkin koejäsenen kuudestakymmenestä kasvista arvioitiin viikoittain kolmen ylimmän lehden vihreän lehtialan kesto.

Tulokset osoittavat, ettă viljan käăpiökasvuviroosi sel- văsti heikensi tutkittuja satokomponentteja, lyhensi kortta ja aiheutti satotappioita kaikille koejäsenille. Samoin heikkeni satoindeksi, joka kuvaa jyvien osuutta maanpaalllisen kasvimassan painosta. Satotappiot aiheutuivat siitä, ettă BYDV-saastunta selvăsti lyhensi vihreän lehtialan kestoa, joka oli lyhin altteimmalla koejäsenellă Velillă.

Satotappiot olivat sită suurempia, mitär aikaisemmin kirvat siirsivăt viruksen kauroihin, kuten vuonna 1988 , jolloin kirvoja oli runsaasti. Toisaalta myöhäinenkin BYDV-saastunta, kuten vuonna 1986, heikensi satoa. 